\title{
LDL-c as a predictor of hormonal status and determining factor for therapy of breast cancer patients
}

\author{
Reynard Budy Setiawan 1, ${ }^{*}$, Desak Gede Agung Suprabawati 2 and Jusak Nugraha ${ }^{3}$ \\ ${ }^{1}$ Department of Surgery Faculty of Medicine, University of Airlangga, Surabaya-East Java. Indonesia. \\ 2 Division of Oncology, Department of Surgery, Faculty of Medicine, University of Airlangga, Surabaya-East Java. Indonesia. \\ ${ }^{3}$ Department of Clinical Pathology, Faculty of Medicine, University of Airlangga, Surabaya-East Java. Indonesia.
}

Magna Scientia Advanced Biology and Pharmacy, 2021, 02(02), 023-031

Publication history: Received on 08 April 2021; revised on 19 May 2021; accepted on 22 May 2021

Article DOI: https://doi.org/10.30574/msabp.2021.2.2.0024

\begin{abstract}
Background: Immunohistochemical testing is important in determining clinical diagnosis and therapy, and is useful as a prognostic and predictive factor, but it is not easy to do and is not always available. Breast cancer patient with higher low-density-lipoprotein cholesterol [LDL-c]. level tends to have larger tumor size, higher grade, higher proliferation rate, positive Human Epidermal growth factor Receptor-2 (HER2-neu) and occasionally come at late stage. High LDL-c receptors are found on the surface of breast cancer cells, where cancer cells will take up cholesterol in serum, and a metabolite of 27-hydroxycholesterol cholesterol will affect Estrogen Receptor- $\alpha$.
\end{abstract}

Methods: Analytical observational study by cross sectional method, during July 2020 - November 2020, at Oncology Clinic Dr. Soetomo Hospital Surabaya with a total sample size of 42 . The data obtained were analyzed using the SPSS version 23.0 program, regression test and Chi-Square were performed for characteristic analysis and Chi-Square Fischer's Exact Test were performed for correlation test between lipid profiles with hormonal status.

Results: The mean value of LDL-c was $117.88 \pm 33.89 \mathrm{mg} / \mathrm{dL}$. In the analysis of the correlation between LDL-c and hormonal status, it was found that the majority of patients who had positive hormonal status had LDL-c levels of $\leq 160$ $\mathrm{mg} / \mathrm{dL}$ with $\mathrm{p}$ value $=0.049$. ROC analysis shown LDL-c cut-off point of $132 \mathrm{mg} / \mathrm{dL}$, $\mathrm{p}$ value $=0.034(\mathrm{OR} 5.031,95 \% \mathrm{CI}$ $1.159-21.848)$, sensitivity $46.7 \%$ and specificity $83.35 \%$.

Conclusion: There is a statistically significant relationship between LDL-c levels and hormonal status with the cut-off point of $132 \mathrm{mg} / \mathrm{dL}$. The increase in LDL-c in serum increases the tendency of negative hormonal status, therefore LDLc levels can be considerate in determining the therapy for breast cancer patients.

Keywords: LDL-c; Hormonal status; Immunohistochemistry; Breast cancer

\section{Introduction}

Breast cancer has 4 clinical subtypes based on the molecular subtypes, which are luminal A, luminal B, HER2 and basal type [1]. Classifying tumor according to its histopathology, stage and molecular subtype using immunohistochemical evaluation is important in determining the correct corresponding diagnosis and therapy and is also useful to be utilized as a prognostic and predictive factor [2,3]. Patients with positive hormonal receptor status examinations (estrogen and progesterone receptors) will get advantage from hormonal therapy [4,5]. Unfortunately, immunohistochemical testing to determine the molecular subtypes of breast cancer is generally not easy to do and is not always available in all health care centers [6]. A study on 1779 subjects in 2016 found that women with obesity, metabolic syndrome,

\footnotetext{
${ }^{*}$ Corresponding author: Setiawan Reynard Budy

Department of Surgery Faculty of Medicine, University of Airlangga, Surabaya - East Java. Indonesia. 
hyperinsulinemia, or insulin resistance were at greater risk of developing breast cancer [7]. Patients with obesity tend to experience metabolic syndromes such as glucose intolerance, lower high-density-lipoprotein cholesterol [HDL-c]., higher LDL-c, high triglyceride levels, and hypertension [8]. Breast cancer patients with high LDL-c levels tend to have the characteristics of having a larger tumor size, a higher degree of cancer cell differentiation, a higher proliferation rate, positive HER2-neu status and is often found at an advanced stage [9]. High LDL-c receptors are found on the surface of breast cancer cells, where cancer cells will take up cholesterol in serum, and 27-hydroxycholesterol cholesterol metabolites will affect ER- $\alpha$, Liver X Receptor, PI3K/AKT, Plasminogen Activator Inhibitor-1 thus stimulating cell proliferation, epithelial-mesenchymal transition, angiogenesis and invasion, migration and metastasis of breast cancer cells $[9,10]$. In in-vitro studies, LDL-c was found to influence the proliferation of cancer cells with negative Estrogen Receptors [ER]. [11]. A nested case-control study with 287 samples between 1994 and 1998, found that 27 hydroxycholesterol [27-HC]. levels were associated with the ER- $\beta$ marker in breast cancer and 27-HC levels associated with circulating cholesterol levels. However, from previous epidemiological studies, found there was no association between cholesterol levels and breast cancer risk [12,13]. In vitro research in 2017, found an effect of 27-HC in upregulating the ER- $\beta$ receptors on prostate cancer cells, but similar results were not found on the ER- $\alpha$ receptors on breast cancer cells. The presence of receptor upregulation increases the effect of 27-HC on modulation of estrogen receptors [14]. LDL-c examination is an easy and inexpensive clinical laboratory examination, and is available in almost all health care centers with clinical laboratories. Examination the correlation of LDL-c levels to the hormonal status of breast cancer patients is an important step in the evaluation to further determine the useful aspects of the LDL-c test in determining the hormonal status of breast cancer patients.

\section{Material and methods}

This cross-sectional analytic observational study altogether with the samples used for this study were all obtained from breast cancer patients at the Oncology Clinic of Dr. Soetomo Public Hospital, Surabaya during July 2020 - November 2020. Patients with a diagnosis of breast cancer who had not undergone breast surgery, had undergone a mastectomy or breast tumor biopsy in less than 1 month, and had never received prior chemotherapy to being included in the study. Patients using lipid lowering agent therapy, undergoing herbal treatment to reduce cholesterols levels, experienced recurrence, and with histopathological results other than breast carcinoma, such as sarcomas, phyllodes and lymphoma in the breast were excluded from the study. The lipid panel was examined using direct colorimetric method with Siemens Dimension EXL-200 and the results were triglycerides, total cholesterol, HDL-c and LDL-c. The lipid panel data were stratified with a limit of $200 \mathrm{mg} / \mathrm{dL}$ for total cholesterol and triglycerides, $40 \mathrm{mg} / \mathrm{dL}$ for HDL-c and $160 \mathrm{mg} / \mathrm{dL}$ for LDL-c. Hormonal status was determined from immunohistochemical examination with interpretation according to the Allred scoring system. The data obtained were analyzed with the SPSS version 23.0 program. Data regarding the hormonal status in each sample will be grouped based on age, obesity status and histopathological type, then regression and Chi-Square tests are carried out. Data regarding total cholesterol, triglycerides, HDL-c, LDL-c/HDL-c ratio and LDL$\mathrm{c}$ to hormonal status will be analyzed using the Chi-Square - Fischer's Exact test.

\section{Results}

The study was conducted for 5 months starting from July 2020 to November 2020, with 42 subjects being eligible and included in the study. The study subjects consisted of 42 women (100\%) whose patient characteristics are being described in the Table 1.

The research subjects consisted of 42 women (100\%) with the most age being 35-50 years, 26 patients (61.9\%) followed by 13 patients (31\%) aged $>50$ years and 3 patients $<35$ years old $(7.1 \%)$. Based on the type of anatomical pathology, the most common was ductal carcinoma, namely 29 patients (69\%) followed by other types of carcinoma as many as 9 patients (21.4\%) and lobular carcinoma by 4 patients (9.5\%). Based on the characteristics of Body Mass Index [BMI]. the most were found in normal conditions, namely 29 patients (69\%) followed by overweight as many as 9 patients $(21.4 \%)$ and 4 patients $(9.5 \%)$ who were obese. The research subjects who are under 35 years of age with negative hormonal status consisted of 1 subject and 2 subjects with positive hormonal status. Subjects who are between 35-50 years old with negative hormonal status consisted of 8 subjects and who are the hormonal status positive consisted of 18 subjects. In addition, subjects who are more than 50 years old with negative hormonal status consisted of 6 subjects and positive hormonal status consisted of 7 subjects. Subjects with the result of ductal carcinoma in anatomical pathology examination with negative hormonal status consisted of 11 subjects and 18 subjects with positive hormonal status. Lobular carcinoma with negative hormonal status consisted of 1 subject and 3 subjects with positive hormonal status. The data showed subjects with normal BMI and negative hormonal status consisted of 8 subjects and 21 subjects with positive hormonal status. The subject who are the BMI overweight and negative hormonal status 
consisted of 5 subjects and 4 subjects with positive hormonal status. Subjects who are BMI obesity with negative hormonal status consisted of 2 subjects and with positive hormonal status consisted of 2 subjects.

Table 1 Characteristics of Age, Results of Anatomical Pathology, and BMI of Research Subjects

\begin{tabular}{|c|c|c|c|c|c|c|}
\hline \multicolumn{2}{|c|}{$\begin{array}{l}\text { Subject } \\
\text { Characteristics }\end{array}$} & $\begin{array}{l}\text { Negative } \\
\text { Hormonal } \\
\text { Status }\end{array}$ & $\begin{array}{l}\text { Positive } \\
\text { Hormonal } \\
\text { Status }\end{array}$ & Total & $\begin{array}{l}P \\
\text { value }\end{array}$ & $\begin{array}{l}\text { OR } \\
(95 \% \mathrm{CI})\end{array}$ \\
\hline \multirow{6}{*}{ Age } & \multirow{2}{*}{$\begin{array}{l}<35 \text { years } \\
\text { old }\end{array}$} & 1 & 2 & 3 & \multirow{6}{*}{0.637} & \multirow{6}{*}{ NA } \\
\hline & & $6.7 \%$ & $7.4 \%$ & $7.1 \%$ & & \\
\hline & \multirow{2}{*}{$\begin{array}{l}35-50 \\
\text { years old }\end{array}$} & 8 & 18 & 26 & & \\
\hline & & $53.3 \%$ & $66.7 \%$ & $61.9 \%$ & & \\
\hline & \multirow{2}{*}{$\begin{array}{l}>50 \text { years } \\
\text { old }\end{array}$} & 6 & 7 & 13 & & \\
\hline & & $40 \%$ & $25.9 \%$ & $31.0 \%$ & & \\
\hline \multirow{6}{*}{$\begin{array}{l}\text { Results of } \\
\text { Anatomical } \\
\text { Pathology }\end{array}$} & \multirow{2}{*}{$\begin{array}{l}\text { Ductal } \\
\text { carcinoma }\end{array}$} & 11 & 18 & 29 & \multirow{6}{*}{0.867} & \multirow{6}{*}{ NA } \\
\hline & & $73.3 \%$ & $66.7 \%$ & $69.0 \%$ & & \\
\hline & \multirow{2}{*}{$\begin{array}{l}\text { Lobular } \\
\text { carcinoma }\end{array}$} & 1 & 3 & 4 & & \\
\hline & & $6.7 \%$ & $11.1 \%$ & $9.5 \%$ & & \\
\hline & \multirow{2}{*}{$\begin{array}{l}\text { Other type } \\
\text { carcinoma }\end{array}$} & 3 & 6 & 9 & & \\
\hline & & $20 \%$ & $22.2 \%$ & $21.4 \%$ & & \\
\hline \multirow{6}{*}{ BMI } & \multirow[t]{2}{*}{ Normal } & 8 & 21 & 29 & \multirow{6}{*}{0.255} & \multirow{6}{*}{ NA } \\
\hline & & $53.3 \%$ & $77.8 \%$ & $69.0 \%$ & & \\
\hline & Overweight & 5 & 4 & 9 & & \\
\hline & & $33.3 \%$ & $14.8 \%$ & $21.4 \%$ & & \\
\hline & \multirow[t]{2}{*}{ Obesity } & 2 & 2 & 4 & & \\
\hline & & $13.3 \%$ & $7.4 \%$ & $9.5 \%$ & & \\
\hline
\end{tabular}

Based on the characteristics of the serum lipid profile, normal HDL-c levels were 37 patients (88.1\%), normal triglyceride levels were 39 patients (92.0\%), normal total cholesterol levels were 30 patients $(71.4 \%)$, and LDL-c/HDLc ratio $>2,426$ as many as 23 patients $(54.8 \%)$.

In the analysis of the relationship between total cholesterol and hormonal status, it was found that the majority of patients with positive hormonal status had total cholesterol levels $\leq 200 \mathrm{mg} / \mathrm{dL}$ ) with $\mathrm{p}$ value $=0.292$ (OR 2.333; 95\% CI 0.590-9.227). In the analysis of the relationship between triglycerides and hormonal status, it was found that the majority of patients who had positive hormonal status had triglyceride levels $\leq 200 \mathrm{mg} / \mathrm{dL}$ with $\mathrm{p}$ value $=0.541$. In the analysis of the correlation between HDL-c and hormonal status, it was found that the majority of patients with positive hormonal status had HDL-c levels $>40 \mathrm{mg} / \mathrm{dL}$ with $\mathrm{p}$ value $=0.142$. In the analysis of the correlation between the LDLc/HDL-c ratio with hormonal status, it was found that the majority of patients with positive hormonal status had a LDLc/HDL-c ratio $\leq 2.426$ with $\mathrm{p}$ value $=0.337$ (OR 2.154; CI 95\% 0.580-8,001). The mean value of LDL-c was $117.88 \pm$ $33.89 \mathrm{mg} / \mathrm{dL}$, with a maximum value of $229 \mathrm{mg} / \mathrm{dL}$ and a minimum of $64 \mathrm{mg} / \mathrm{dL}$. Most of the patients had positive hormonal status, as many as 27 patients $(64.28 \%)$. The correlation between cholesterol levels and hormonal status of breast cancer patients was tested using the chi-square test (Table 2), it was found that there was a significant correlation between cholesterol levels and hormonal status of breast cancer patients with $p$ value $=0.049$ (OR 5,333; CI 95\% 1,095$25,985)$. 
Table 2 Correlation between Lipid Panels on Hormonal Status

\begin{tabular}{|c|c|c|c|c|c|c|}
\hline \multicolumn{2}{|c|}{ Subject Characteristics } & \multirow{2}{*}{$\begin{array}{l}\text { Negative } \\
\text { Hormonal } \\
\text { Status }\end{array}$} & \multirow{2}{*}{$\begin{array}{l}\text { Positive } \\
\text { Hormonal } \\
\text { Status }\end{array}$} & \multirow{2}{*}{\begin{tabular}{|l} 
Total \\
30 \\
\end{tabular}} & \multirow{5}{*}{$\begin{array}{l}\text { P value } \\
0.292\end{array}$} & \multirow{4}{*}{$\begin{array}{c}\text { OR }(\mathbf{9 5} \% \mathrm{CI}) \\
\\
2.333(0.590 \\
9.227)\end{array}$} \\
\hline \multirow{4}{*}{$\begin{array}{c}\text { Total } \\
\text { Cholesterol }\end{array}$} & \multirow[t]{2}{*}{$\leq 200 \mathrm{mg} / \mathrm{dL}$} & & & & & \\
\hline & & $60.0 \%$ & $77.8 \%$ & $71.4 \%$ & & \\
\hline & \multirow[t]{2}{*}{$>200 \mathrm{mg} / \mathrm{dL}$} & 6 & 6 & 12 & & \\
\hline & & $40.0 \%$ & $22.2 \%$ & $28.6 \%$ & & \\
\hline \multirow{4}{*}{ Triglycerides } & \multirow[t]{2}{*}{$\leq 200 \mathrm{mg} / \mathrm{dL}$} & 15 & 24 & 39 & \multirow{4}{*}{0.541} & \multirow{4}{*}{ NA } \\
\hline & & $100 \%$ & $88.9 \%$ & $92.9 \%$ & & \\
\hline & \multirow[t]{2}{*}{$>200 \mathrm{mg} / \mathrm{dL}$} & 0 & 3 & 3 & & \\
\hline & & $0.0 \%$ & $11.1 \%$ & $7.1 \%$ & & \\
\hline \multirow{4}{*}{ HDL-c } & \multirow[t]{2}{*}{$>40 \mathrm{mg} / \mathrm{dL}$} & 15 & 22 & 37 & \multirow{4}{*}{0.142} & \multirow{4}{*}{ NA } \\
\hline & & $100 \%$ & $81.5 \%$ & $88.1 \%$ & & \\
\hline & \multirow[t]{2}{*}{$\leq 40 \mathrm{mg} / \mathrm{dL}$} & 0 & 5 & 5 & & \\
\hline & & $0.0 \%$ & $18.5 \%$ & $11.9 \%$ & & \\
\hline \multirow{4}{*}{$\begin{array}{l}\text { LDL-c/HDL-c } \\
\text { ratio }\end{array}$} & \multirow[t]{2}{*}{$\leq 2.426$} & 5 & 14 & 19 & \multirow{4}{*}{0.337} & \multirow{4}{*}{$\begin{array}{l}2.154(0.580- \\
\quad 8.001)\end{array}$} \\
\hline & & $33.3 \%$ & $51.9 \%$ & $45.2 \%$ & & \\
\hline & \multirow[t]{2}{*}{$>2.426$} & 10 & 13 & 23 & & \\
\hline & & $66.7 \%$ & $48.1 \%$ & $54.8 \%$ & & \\
\hline \multirow[t]{4}{*}{ LDL-C } & \multirow[t]{2}{*}{$>160 \mathrm{mg} / \mathrm{dL}$} & 6 & 3 & 9 & \multirow{4}{*}{0.049} & \multirow{4}{*}{$\begin{array}{l}5.333(1.095- \\
25.985)\end{array}$} \\
\hline & & $40.0 \%$ & $11.2 \%$ & $21.4 \%$ & & \\
\hline & \multirow[t]{2}{*}{$\leq 160 \mathrm{mg} / \mathrm{dL}$} & 9 & 24 & 33 & & \\
\hline & & $60.0 \%$ & $88.8 \%$ & $78.6 \%$ & & \\
\hline
\end{tabular}

Table 3 Correlation between LDL-c level at cut-off value and hormonal status

\begin{tabular}{|c|c|c|c|c|c|c|}
\hline \multicolumn{2}{|c|}{ Subject } & $\begin{array}{l}\text { Negative } \\
\text { Hormonal } \\
\text { Status }\end{array}$ & $\begin{array}{l}\text { Positive } \\
\text { Hormonal } \\
\text { Status }\end{array}$ & Total & P value & OR $(95 \% C I)$ \\
\hline \multirow[t]{4}{*}{ LDL-c } & $\leq 132 \mathrm{mg} / \mathrm{dL}$ & 8 & 23 & 31 & \multirow{4}{*}{0,034} & \multirow{4}{*}{$\begin{array}{l}5.031 \\
(1.159-21.848)\end{array}$} \\
\hline & & $53.3 \%$ & $85.2 \%$ & $73.8 \%$ & & \\
\hline & \multirow[t]{2}{*}{$>132 \mathrm{mg} / \mathrm{dL}$} & 7 & 4 & 11 & & \\
\hline & & $46.7 \%$ & $14.8 \%$ & $26.2 \%$ & & \\
\hline \multirow[t]{2}{*}{ Total } & & 15 & 27 & 42 & & \\
\hline & & $100 \%$ & $100 \%$ & $100 \%$ & & \\
\hline
\end{tabular}

From the results of the analysis on the ROC (Figure 1), the cut-off point of the LDL-c level was $132 \mathrm{mg} / \mathrm{dL}$, where the LDL-c level of more than $132 \mathrm{mg} / \mathrm{dL}$ correlated with a tendency to negative hormonal status with $\mathrm{p}$ value $=0.034(\mathrm{OR}$ $5.031,95 \%$ CI 1.159-21.848) and LDL-c levels > $132 \mathrm{mg} / \mathrm{dL}$ had a tendency to negative hormonal status by 5.031 times with a sensitivity of $46.7 \%$ and specificity of $83.35 \%$ (Table 3 ). 


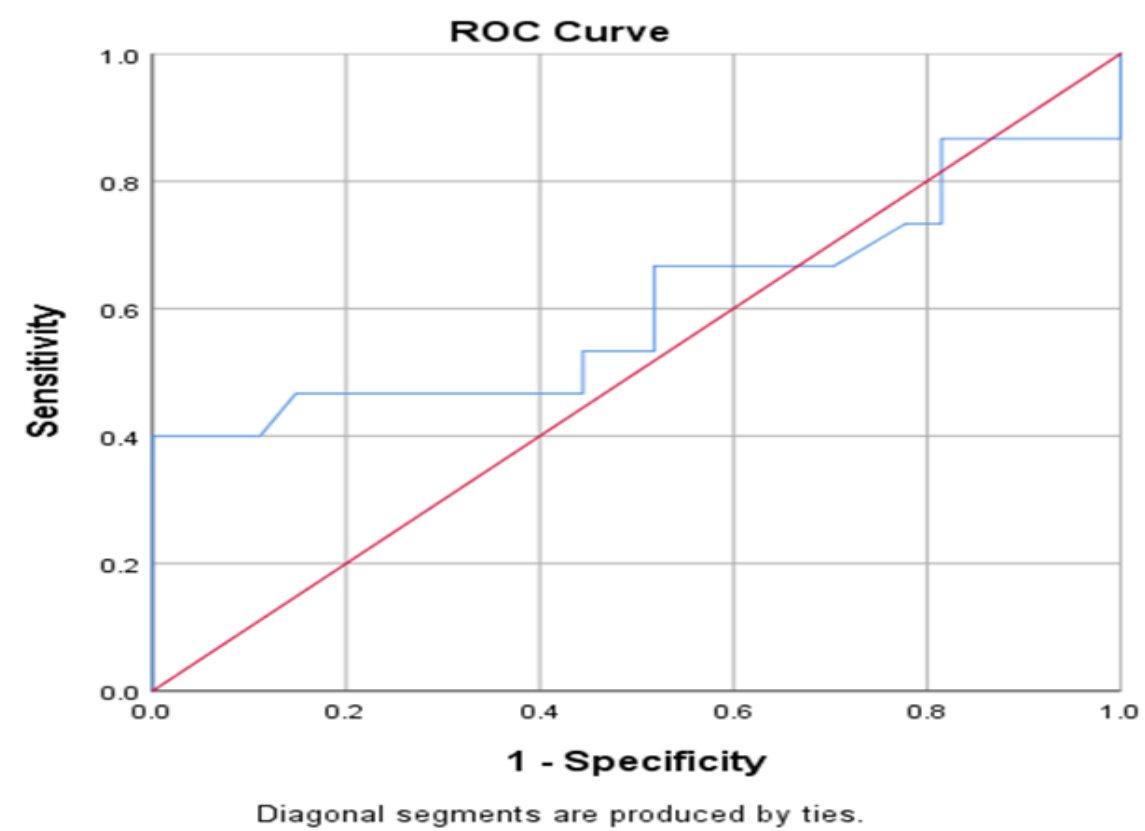

Figure 1 ROC analysis between LDL-c level and hormonal status

\section{Discussion}

The age range of our patients were between $35-50$ years, where 26 patients $(61.9 \%)$ were in that range. This is in accordance with previous studies where the age of most breast cancer is in the age range of 35-50 years. The most common histopathological finding in our study was ductal carcinoma, accounted for 69\%, where $64.9 \%$ of the hormonal status was luminal type. The results of this study are consistent with the study conducted by Yue et al. (2016), where the tumour subtypes were mostly dominated by positive hormonal status (luminal type) [15]. Based on the BMI characteristics, 29 patients (69\%) had normal BMI. There was no significant relationship between obesity and hormonal status. This result is different from the literature review which stated that obesity causes a tendency of breast cancer patients with negative hormonal receptors by 2.2-fold (95\% CI 0.9-5.8) [16]. Other literature also stated that women who were overweight or obese (having body mass index of more than $25 \mathrm{~kg} / \mathrm{m}^{2}$ was associated with a greater risk for developing invasive breast cancer compared to women who were not overweight or obese. Interestingly, in this literature the risk of having invasive breast cancer was predominantly higher in a case with ER-positive [17]. Although the effects of obesity on breast cancer risk or prognosis are multifactorial, several mechanism have been proposed. This may be related with obesity-induced hyperinsulinemia, increased levels of insulin-like growth factors, adipokines, increased inflammatory immune cells, and increased inflammatory cytokines in all subtypes of breast cancer [18]. Nevertheless, in this study we found no significant correlation between obesity and the hormonal status of breast cancer. Some differences from several literatures and our findings can be caused by socio-geographical differences between the two studies, where this condition can affect differences in diet and daily activities. In addition, race differences between these two studies can also be a cause of these differences. Nonetheless, study by Law et al., also stated that the mechanism by which obesity affect breast cancer can happen in all subtypes of breast cancer not necessarily a determinant of hormonal status of breast cancer [18].

In term of total cholesterol levels, there was no statistically significant relationship between total cholesterol levels and hormonal status of breast cancer patients, $p$ value $=0.292$ ( $p>0.05$; OR 2.333; 95\% CI 0.590-9.227). Total cholesterol produces a metabolite in the form of 27-HC. It is one of the most prevalent oxysterols, found to be an endogenous Selective Estrogen Receptor Modulator (SERM) and Liver X Receptor (LXR) antagonist [11]. 27-HC is mainly transported in esterified form where this metabolite acts as SERM in cancer cells which contribute to the development of breast cancer through a mechanism that promotes migration and invasion, through STAT-3/MMP9 and STAT-3/EMT, in both ER-positive and ER-negative breast cancer cells. 27-HC causes greater macrophage infiltration and exacerbation of inflammation in the regulation of hypercholesterolemia, thus providing a link between inflammation and cancer development [12,13]. 
In study conducted by Cedó et al. in 2019 stated that the first evidence for 27-HC's role in breast cancer began with the study that 27-HC played a role in stimulating the growth of cancer cell in ER-positive breast cancer cell and did not show a growth stimulation in ER-negative breast cancer cells. 27-HC also hasten the myeloid immune cell function. It increased the number of neutrophil but decreased the cytotoxic CD8+ T cells which responsible for controlling cancer cells. It was also stated that the discovery of 2-HC as an endogenous ER ligand which promotes the growth of ER-positive breast cancer could help explain why certain breast cancer patients with positive hormonal status are not responding well to aromatase inhibitors. In this case, 27-HC act as an alternate esterogenic ligand [11]. However, the correlation between total cholesterol as a precursor of $27-\mathrm{HC}$ on hormonal status was not found in this study. The reason is probably due to the fact that in vitro findings may not represent the in vivo findings.

Beside total cholesterol, there was no correlation between triglyceride levels and hormonal status of breast cancer patients with $p$ value $=0.541$ ( $p>0.05)$. Triglycerides are a form of blood cholesterol obtained from absorption of fat in the digestive tract. This form will still undergo further metabolism in the body to be able to affect cell metabolism. Triglycerides serve as an independent source for fatty acid oxidation, which is considered as an important process for cell proliferation and tumor growth. Triglycerides do not affect the development of hormonal status in breast cancer. This suggests that the dominant role in luminal type breast cancer is probably played by lipoproteins and not by triglycerides [19].

There was no relationship between HDL-c levels and hormonal status of patients, with a value of $p$ value $=0.142(p>$ $0.05)$. The results of this study are inconsistent with previous studies which showed that increased HDL-c increased the risk of positive Estrogen Receptor (ER) breast cancer [11].

HDL-c itself contains a single copy or multiple copies of apolipoprotein A-I, the most abundant HDL-c apolipoprotein. It plays role in promoting cholesterol release from cells. It possesses anti-inflammatory, antioxidant, and antiapoptotic properties. It also influences innate immunity [20]. In study conducted by Cedó et al., it was also stated the controversy in term of HDL-c levels and breast cancer risk. It was stated that in vitro analysis had shown that HDL stimulated proliferation in both ER-positive and ER-negative breast cancer. The controversy related with the role of HDL-c in hormonal breast cancer is that some studies stated that apoA-1 in HDL-c was inversely related with the development of breast cancer [21], but other study stated that it was positively associated with breast cancer [22]. It is important to note that clinical or methodological differences in study design, including variation in geographic area, menopausal status, number of cases, or length of follow-up, may explain the differences found in these studies.

There was no relationship between LDL-c/HDL-c ratio and hormonal status of breast cancer patients with a $\mathrm{p}$ value = 0.337 ( $p>0.05$; OR 2.154; 95\% CI 0.580-8.001). This is consistent with a study by Furberg et al. (2005) where the LDLc/HDL-c ratio is a strong predictor of estradiol concentration, so that this ratio is more sensitive as a marker of breast cancer risk rather than hormonal status in breast cancer, a LDL-c/HDL-c ratio $\geq 2.08$ was found to be have more exposure to estradiol levels [8]. Circulating estradiol itself is thought to play a major role in the development of breast cancer not necessarily breast cancer in certain hormonal status. There is no significant correlation found in our study also provides an insight that LDL-c/HDL-c ratio is not a determinant for certain subtype of breast cancer.

The relationship between LDL-c levels and hormonal status of breast cancer patients was tested using the Chi-Square test, it was found that there was a significant relationship between LDL-c levels and hormonal status of breast cancer patients with $\mathrm{p}$ value $=0.049(\mathrm{p}<0.05$; OR 5,333; 95\% CI 1,095-25,985) which means that there is a statistically significant relationship between LDL-c levels and hormonal status, where LDL-c $\leq 160 \mathrm{mg} / \mathrm{dL}$ will tend to have a positive hormonal status of 5.333 times compared to high cholesterol. The results of this study are in accordance with research from Cedó et al (2019) where High LDL-c was found to influence proliferation in ER-negative cells [11]. Cancer cells that proliferate will experience an increased need for cholesterol. An increase need of cholesterol by breast cancer tissue is demonstrated by an increase in LDL-R expression [23]. LDL-c primarily promotes proliferation and migration in ERnegative cells, but this is not evident in ER-positive cell lines. This difference between the two cell types is related to the greater ability of ER-negative cells to take up, store, and utilize exogenous cholesterol due to increased acyl-CoA: cholesterol acyltransferase 1 (ACAT-1) activity. ER-negative breast cancer cells through different mechanisms take up and store cholesterol. This explains the effect of a low-fat diet on ER-negative breast cancer recurrence [9,11].

The increase in LDL-c in serum plays a role in increasing free cholesterol levels in the intracellular area and will result in the build-up of ester cholesterol. The accumulation of ester cholesterol will trigger an increase in LDL-R expression, which is found to be more dominant in breast cancer cells with negative hormonal status. The cholesterol metabolite, in the form of $27-\mathrm{HC}$, was proven in-vitro to not be able to show a modulation effect of ER- $\alpha$ on breast cancer cells. This also increases the tendency of negative hormonal status to high cholesterol levels. 
Based on study conducted by Antalis et al. in 2009, it was found that ER negative breast cancer cells are able to take up higher LDL-c in greater extent. This ability is associated with higher activity levels of ACAT1, higher mRNA protein, higher protein levels of CAV1, and lower de novo cholesterol synthesis [24]. The greater capability of basal-like ER negative breast cancer cells to make and store lipid is known as "lipid accumulating phenotype". This phenotype may develop in precursor cancer cells as a result of mutation or as a result of tumor hypoxia. In this case, this ability may enable cells to take high free fatty acids and LDL-c. The reason behind the more prominent effect of ER-negative breast cancer cell to proliferate under LDL may also be bridged by ACAT1. It was found that the mRNA expression of ACAT1 is increased in ER-negative breast cancer cell. Inhibition of ACAT1 itself may reduce the proliferation of LDL induced proliferation [11].

Cholesteryl ester accumulation due to increased LDL-c internalization which also happens in ER-negative breast cancer cells is associated with breast cancer proliferation and patients with higher LDL-R expression is found to be associated with a worse prognosis especially in patient who undergo systemic therapy. Overall triple-negative breast cancer patients with higher circulating LDL-c and higher expression of LDL-R are at risk disease progression and disease-free survival [11].

In this study, a cut-off point was obtained from the correlation between cholesterol levels and the hormonal status of tumour cells at a value of $132 \mathrm{mg} / \mathrm{dL}$, where cholesterol levels $>132 \mathrm{mg} / \mathrm{dL}$ had a tendency to negative hormonal status by 5.031 times with a sensitivity of $46.7 \%$ and specificity $83.35 \%$. The results of this study indicate that LDL-c level can be used as a consideration in determining the therapy for breast cancer patients. In the conditions where immunohistochemistry testing is not readily available, LDL-c levels $\leq 132 \mathrm{mg} / \mathrm{dL}$ can suggest the need for hormonal therapy, while LDL levels > $132 \mathrm{mg} / \mathrm{dL}$ propose the need for lipid lowering therapy.

\section{Conclusion}

High LDL level is significantly correlated with negative hormonal status in breast cancer patients; however, HDL-c, total cholesterol level, triglyceride level and LDL-c/HDL-c ratio is not significantly correlated with hormonal status of breast cancer. A cut-off value of $132 \mathrm{mg} / \mathrm{dL}$, LDL-c $>132 \mathrm{mg} / \mathrm{dL}$ shows a tendency of a breast cancer to possess negative hormonal status by 5.031 times.

\section{Compliance with ethical standards}

\section{Author Contribution}

Conception and design: All authors; Administrative support: Reynard Budy Setiawan; Provision of study materials or patients: All authors; Collection and assembly of data: Reynard Budy Setiawan; Data analysis and interpretation: All authors; Manuscript writing: All authors; Final approval of manuscript: All authors.

\section{Acknowledgments}

Presented at International Conference The $4^{\text {th }}$ Aceh Surgery Update 2021 "Current Update on COVID-19 Clinical and Surgery.

\section{Disclosure of conflict of interest}

All authors have completed the ICMJE uniform disclosure form. The authors have no conflicts of interest to declare.

\section{Statement of ethical approval}

Ethical statements issued by Ethical Committee RSUD $\mathrm{dr}$ Soetomo Surabaya, Indonesia. Letter no. 0128/LOE/301.4.2/X/2020.

\section{Statement of informed consent}

Informed consent was obtained from all individual participants included in the study. 


\section{References}

[1] Curtis C, Shah SP, Chin S, et al. (2012). The genomic and transcriptomic architecture of 2,000 breast tumours reveals novel subgroups. Nature, 486, 346-352.

[2] Zaha DC. (2014). Significance of immunohistochemistry in breast cancer. World J Clin Oncol, 5(3), 382-393.

[3] Russnes HG, Lingjærde OC, Caldas C. (2017). Breast cancer molecular stratification- from intrinsic subtypes to integrative clusters Hege. Am J Pathol. Epub ahead of print.

[4] Goldhirsch A, Winer EP, Coates AS, et al. (2013). Personalizing the treatment of women with early breast cancer : highlights of the St Gallen International Expert Consensus on the Primary Therapy of Early Breast Cancer 2013. Ann Oncol, 24, 2206-2223.

[5] Chand P, Garg A, Singla V, et al. (2018). Evaluation of Immunohistochemical Profile of Breast Cancer for Prognostics and Therapeutic Use. Niger J Surg, 24(2),100-106.

[6] Tfayli A, Temraz S, Mrad RA, et al. (2010). Breast Cancer in Low- and Middle-Income Countries : An Emerging and Challenging Epidemic. J Oncol. Epub ahead of print.

[7] Agresti R, Meneghini E, Baili P, et al. (2016). Association of adiposity , dysmetabolisms , and inflammation with aggressive breast cancer subtypes : a cross-sectional study. Breast Cancer Res Treat. Epub ahead of print.

[8] Furberg A, Jasienska G, Bjurstam N, et al. (2004). Metabolic and Hormonal Profiles: HDL Cholesterol as a Plausible Biomarker of Breast Cancer Risk. The Norwegian EBBA Study. Cancer Epidemiol Biomarkers Prev, 14, 33-40.

[9] Rodrigues C, Fonseca I, Dias S, et al. (2014). Plasma level of LDL-cholesterol at diagnosis is a predictor factor of breast tumor progression. BMC Cancer, 14, 1-10.

[10] Marwarha G, Raza S, Hammer K, et al. (2017). 27-hydroxycholesterol : A novel player in molecular carcinogenesis of breast and prostate cancer. Chem Phys Lipids, 207, 108-126.

[11] Cedó L, Reddy ST, Mato E, et al. (2019). HDL and LDL : Potential New Players in Breast Cancer Development. J Clin Med, 8, 1-21.

[12] Cornet C Le, Walter B, Sookthai D, et al. (2020). Circulating 27-hydroxycholesterol and breast cancer tissue expression of CYP27A1, CYP7B1, LXR- $\beta$, and ER $\beta$ : results from the EPIC-Heidelberg cohort. Breast Cancer Res, 22(23), 1-10.

[13] He S, Nelson ER. (2017). 27-Hydroxycholesterol, an endogenous Selective Estrogen Receptor Modulator. Maturitas, 104, 29-35.

[14] Raza S, Meyer M, Goodyear C, et al. (2017). The cholesterol metabolite 27 - hydroxycholesterol stimulates cell proliferation via ER $\beta$ in prostate cancer cells. Cancer Cell Int, 17(52), 1-11.

[15] Yue W, Wang J, Li Y, et al. (2010). Effects of estrogen on breast cancer development: role of estrogen receptor independent mechanisms. Int J Cancer, 127(8), 1748-1757.

[16] Carmichael AR. (2006). Obesity as a risk factor for development and poor prognosis of breast cancer. Br J Obstet Gynaeclogy, 113, 1160-1166.

[17] Baek AE, Nelson ER. (2016). The Contribution of Cholesterol and Its Metabolites to the Pathophysiology of Breast Cancer. Horm Cancer, 7(4), 219-228.

[18] Law JH, Habibi G, Hu K, et al. (2008). Phosphorylated insulin-like growth factor-I/insulin receptor is present in all breast cancer subtypes and is related to poor survival. Cancer Res, 68(24), 10238-10246.

[19] Lofterød T, Mortensen ES, Nalwoga H, et al. (2018). Impact of pre-diagnostic triglycerides and HDL-cholesterol on breast cancer recurrence and survival by breast cancer subtypes. BMC Cancer, 18(1), 1-11.

[20] Mineo C, Shaul PW. (2012). Novel biological functions of high-density lipoprotein cholesterol. Circ Res, 111, 1079-1090.

[21] Huang HL, Stasyk T, Morandell S, et al. (2006). Biomarker discovery in breast cancer serum using 2-D differential gel electrophoresis/MALDI-TOF/TOF and data validation by routine clinical assays. Electrophoresis, 27, 16411650. 
[22] Borgquist S, Butt T, Almgren P, et al. (2016). Apolipoproteins, lipids and risk of cancer. Int J Cancer, 138, 26482656.

[23] Pires LA, Hegg R, Freitas FR, et al. (2012). Effect of neoadjuvant chemotherapy on low-density lipoprotein (LDL) receptor and LDL receptor-related protein 1 (LRP-1) receptor in locally advanced breast cancer. Brazilian J Med Biol Res, 45, 557-564.

[24] Antalis CJ, Arnold T, Rasool T, et al. (2010). High ACAT1 expression in estrogen receptor negative basal-like breast cancer cells is associated with LDL-induced proliferation. Breast Cancer Res Treat, 122, 661-670. 